\title{
Orlando Patterson, his work, and his legacy: a special issue in celebration of the republication of Slavery and Social Death
}

\author{
Fiona Greenland ${ }^{1} \cdot$ George Steinmetz $^{2}$
}

Published online: 10 December 2019

(C) Springer Nature B.V. 2019

\begin{abstract}
The reissue of Orlando Patterson's Slavery and Social Death provides an opportunity to reflect on developments in studies of slavery, postcolonial sociology, and comparativehistorical sociology since the book's initial release in 1982. In this special issue of Theory and Society, contributors from ancient history, anthropology, and sociology examine the book's broader intellectual significance by situating it in Patterson's corpus, covering a range of works including his fiction and scholarly publications, early work on Jamaican slave revolts, and private correspondence with key thinkers. The volume's ambit, then, is not a single book but rather a broader field of social thought. As the articles in this issue demonstrate, the concepts and theories introduced by Patterson are still vital. In some ways, we argue, a Pattersonian sociology has only recently come to its full fruition, thanks to ongoing developments in postcolonial studies, critical race studies, anthropological and historical study of slavery, globalization studies, and feminist theory.
\end{abstract}

Keywords Alienation · Freedom · Historical sociology $\cdot$ Racial capitalism $\cdot$ Slavery $\cdot$ Social death

One always has to be careful not to read history the way the elites and the intellectuals are reading it.

-Patterson, in Scott 2013

Fiona Greenland

fg5t@virginia.edu

George Steinmetz

geostein@umich.edu

1 Department of Sociology, University of Virginia, 130 Ruppel Drive, P.O. Box 400766, Charlottesville, VA 22904, USA

2 Department of Sociology, University of Michigan, 500 S. State Street, Ann Arbor, MI 48109, USA 
In essence, it seems to me that sociology offers tremendous possibilities for women, for Blacks and other minorities to explore their own experiences and develop their own ways of knowing. That's what is exciting about sociology now, and that's why I recommend it over any of the other social sciences. I certainly recommend it over economics. But economics represents, of course, the absolute apotheosis of bare positivism, with its presumptuous claim of a science of economic behavior, which is, in effect a kind of pathetic sort of conformity to a very strongly policed set of intellectual norms.

-Patterson, in Williams 1995 (Figs. 1 and 2)

The reissue of Orlando Patterson's Slavery and Social Death is an opportunity to reflect on developments in studies of slavery, postcolonial sociology, and comparative-historical sociology since the book's initial publication release in 1982. Our contributors in this Theory and Society special issue cover a range of Patterson's works, including his fiction and scholarly publications, his early work on Jamaican slave revolts, and his private correspondence with key thinkers. Slavery and Social Death is one of his seminal works, and we offer several ways to think about that book in the text that follows. The issue's ambit, however, is not a single book by Patterson but rather Patterson's intellectual legacy. As the current articles demonstrate, the concepts and theories introduced by Patterson are still vital. In some ways, a Pattersonian sociology has only just come to its full fruition, thanks to ongoing develop-

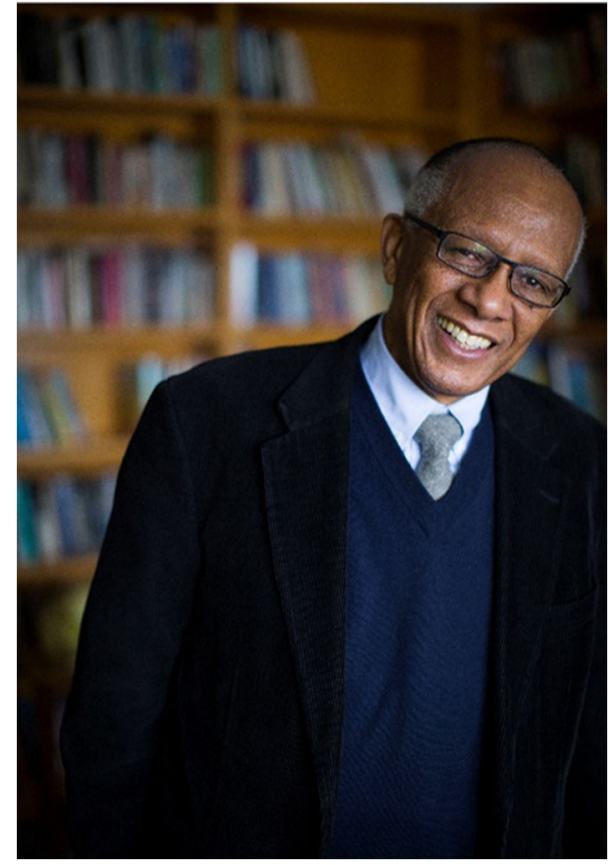

Fig. 1 Orlando Patterson, 2018. Courtesy of Orlando Patterson 


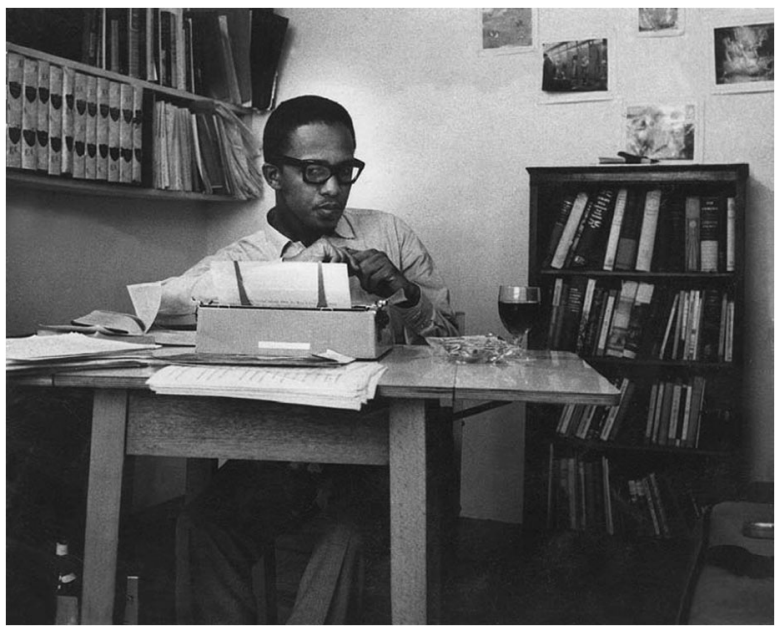

Fig. 2 Photo taken in 1963 of Orlando Patterson revising his first book, The Children of Sisyphus. Courtesy of Orlando Patterson

ments in postcolonial studies, critical race studies, anthropological and historical study of slavery, globalization studies, and feminist theory.

Patterson's contributions are located in an extraordinarily wide realm, encompassing historical sociology, postcolonial fiction, studies of slavery, freedom, and ethnicity, and debates around the epistemology and ethics of social science. This collection can only cover a subset of these interventions. Given the dangers of presentism, against which Patterson has consistently warned, there are good arguments for focusing here on the earlier parts of his long career, namely, the period from The Children of Sisyphus (1964) and The Sociology of Slavery (1967), through Freedom (1991). Because Patterson's earlier work was largely ignored in the period when historical sociology was reconstituted in US sociology starting around 1980, many of these earlier works are unknown to American sociologists.

There are many ways to summarize the contributions of Patterson's writing. In his fiction, two stand out. One concerns the reciprocal, dialogic relations between his fiction and sociology writing and the ways in which this transforms both and informs a unique social epistemology. The second concerns the fictional writing itself, which sheds a unique light on the Jamaican experience, "universalizing" it without subsuming it under a positivistic general model.

Similarly, there is no single gloss on Slavery and Social Death. Here is one contribution that we consider foremost: Patterson liberated the study of slavery from the Greco-Roman and New World contexts that had long been regarded as the "real" cases that mattered for historical work. Instead, he invited us to move beyond the "quintessential slave societies" and take a much longer, much deeper look at slavery's fundamental place in complex human communities. His global, long-range approach stimulated a revolution in scholarship. That revolution, we argue, has happened in fits and starts in sociology, and not always with explicit recognition of Patterson's work. 


\section{Orlando Patterson and American sociology: A long(er)-duration overview}

To understand the intellectual trajectory of Patterson, we need to examine his formative personal and educational experiences. Steinmetz's article in this issue situates Patterson historically and sociologically within the late colonial and postcolonial cultural and social scientific context of Jamaica and London in the 1950s and 1960s. Steinmetz argues that the moment of late colonialism and early decolonization was tied to the restructuring of social and cultural fields in the postcolonies as well as the metropoles. The process of reestablishing field boundaries and internal hegemonies within disciplines took time, and the years immediately following independence saw a temporary but highly productive erosion of such boundaries and destabilization of cultural authority. Entire new generations of cultural producers from the West Indies and Africa entered the fray. This was a precondition of new hybrid roles such as the writersociologist (Patterson), writer-historian (C. R. L. James), or anthropologist-surrealist (Michel Leiris). The field-theoretic effects of decolonization are one source of the cultural and intellectual productivity of that era. Part of Patterson's difference has to do with Jamaica's specific history, however, which the paper then briefly discusses, and part of it has to do with biographical singularities, which Patterson himself has discussed in a long interview with David Scott (2013). Personal biography and the individual social properties that result need to be interwoven with (1) close readings of texts or other artistic, scientific, or cultural products; (2) attention to the structuring and destructuring effects of social fields (literature, sociology) in their respective geospaces and scales (Jamaica, the West Indies, Britain, the British Empire), and (3) the impact of macro-historical events and processes. In Patterson's case these include the collective memory and trauma caused by slavery and its lasting social effects; the opening up of universities in the late colonies, such as the University College of the West Indies; decolonization/Independence; (4) lingering ties between the metropoles and their former colonies in the 1960s, which Edward Kamau Brathwaite called the "time of crossroads" (Walmsley 1992, p. xvii); (5) the current political and intellectual context, in which slavery is being reexamined by a variety of movements.

American sociology may have seemed ready for Orlando Patterson in the late 1960s, when he moved to America, and in the early 1970s, when the boundaries between radical social theory and social science were being breached and when there was experimentation with new forms of cultural production. By 1982, however, when Slavery and Social Death was published, American sociology was no longer ready for Orlando Patterson. His style of interpretive, processual, relational, and historical sociology fell out of favor. Patterson's combination of fiction writing and social science became as incomprehensible to sociologists as messages from outer space. Historical sociologists were counselled to try to force historical processes into the rigid format of J. S. Mill's "method of difference and agreement" or multivariate statistical modeling. Attention to historical contingencies and discontinuities and conjunctural overdetermination was replaced by the mantra of seeking general laws and universal models. The subfield of historical sociology was married to comparativism in the Cold War American context, yielding the hybrid "comparative-historical sociology," something that had never existed in the places where historical sociology was invented, where historicization was related to the idea of singularities and "historical individuals" 
(A. Weber 1997; Oakes 1988). During the 1980s it was profitable (in various ways) for historical sociologists to align their work with the tenets of methodological positivism (Steinmetz 2005). This was all taking place in a wider social context in which the "mechanistic world picture" that had been gaining strength since the early modern era finally showed its "ugly, cold face" in an all-encompassing scientistic worldview governed by "quantification, measurability, and repeatability" (Güttler, et al. 2016, p. 7). Sociologists lack of exposure and resistance to alternative philosophies of social science helped to lodge the scientistic formation firmly within the discipline's common sense.

Only in the 1990s did sociologists begin to reassert a version of sociology incorporating critical reflexivity and critical social theory-for the first time since Weimar Germany and the 1960s. In political sociology this reawakening of a critical-historicalcultural sensibility was seen in several areas. The state was no longer construed as a rational actor or appendage of capitalism but instead as an assemblage of disparate institutions and practices that claim a relative monopoly of power and symbolic domination and are relatively autonomous from other fields (Bourdieu 2013). Culture and discourse were no longer consigned to the role of "dependent" or ancillary "variables" but were reintegrated into the analysis of all aspects of social life, from the most microscopic scales (as discipline and governmentality, via Foucault) to the more macroscopic scales of states and empires (Mamdani 1996; Mitchell, 1988; Said 1979; Steinmetz 1999, 2007). In the study of social movements, identity, discourse, and culture reemerged as central concerns (Laclau and Mouffe 1985). In the sociology of science there was a move away from the postwar focus on scientific organizations, discoveries, technical effectiveness, and awards and citation patterns toward concern with explaining the contents of science and the impact on science of cultural, political, and social processual forces-all things that had interested historians of science between the wars but that were marginalized by the combined forces of positivism and the Cold War afterwards (Steinmetz forthcoming). Most recently, some historical sociologists have become interested in scrutinizing their discipline's implicit and explicit philosophies of science.

Patterson's earlier work provides a hidden foundation for this renaissance, even if it has rarely been cited or acknowledged by historical sociologists. Patterson's thesis concerning the invention of freedom by slaves and the specific role of women slaves in this demonstrates a breakdown of the division of labor between sociology and history. This combination of theorized history and historicized theory makes him difficult to sort into the customary methodological or theoretical "boxes" in sociology. Patterson is probably best known in sociology for his work on American race relations, rather than Slavery and Social Death and Freedom in the Making of Western Culture, much less his fiction. The articles in this special issue situate Patterson's contributions in wider context, using the full span of his writings to rethink some of the common critiques of his work and to highlight conceptualizations that have attracted far less attention.

\section{Patterson's influence today}

The engagement with his work by historians of ancient slavery, in particular, stands out. Ancient historians have, in a sense, been the natural scholarly constituency for Slavery 
and Social Death. The book's sustained engagement with antiquity gives it obvious empirical overlap with classicists' métier. But there is another reason that explains its enthusiastic reception. Just four years before the book's release, Keith Hopkins, by training an ancient historian and sociologist, published Conquerors and Slaves. Covering a roughly 600-year time period from the end of the Republic to the end of Empire, Hopkins charted the causal mechanisms that created mass enslavement, embedded it in the Roman economy, and then shaped it into social thought and cultural practice. These systems were remarkably stable, thanks to the widespread reliance on slaves for social and material standing. As with Patterson, Hopkins devoted substantial attention to the community patterns developed by enslaved persons to support and protect each other. Hopkins's book was not universally loved. Some ancient historians bristled at his adoption of sociological methods, including his incorporation of demography and his refusal to prioritize literary sources. Hopkins's achievement, however, was to demonstrate to his colleagues the power of deductive work based in multiple forms of evidence, including the attestations of the lived experience of slavery. Patterson's book is not Hopkins's, of course. He was not an ancient historian importing sociological methods. But when Slavery and Social Death did appear, in 1982, classicists recognized the contribution for what it was. A major edited volume in 2017 charted the influence of Patterson's thought across a wide range of cases, time periods, and frameworks, with the conclusion that his concepts of social death and freedom have been paradigm-changing for the entire discipline (Bodel and Scheidel 2017).

Patterson's work has also proven inspirational for historians of Nazi Anti-Semitism, Forced Labor, and the Holocaust (Kaplan 1998; Luft 2017). Hannah Arendt already argued that European imperialism in Southern Africa prefigured the Holocaust. Others have suggested that German overseas colonial practices and American frontier ideologies were redeployed in Nazi-occupied Eastern Europe (Arendt 1951; Zimmerer 2004; Steinmetz 2007; Kühne 2013) and that American slavery was one of the models for Nazi race law (Whitman 2017). There is an emerging literature on the treatment of workers in concentration camps and forced laborers in Nazi Germany as slaves (Buggeln 2008, 2014), all of which repeats the judgment of one of Nazism's key slave-drivers, Albert Speer.

Patterson's fiction has been recognized by a number of literary critics as an important contribution to social realism and postcolonialism (Walmsley 1992; Johnson 1992; Francis 2013). In his article in this issue, Steinmetz argues that Patterson should also be considered the first postcolonial sociologist. Patterson's first novel, The Children of Sisyphus, can be read contrapuntally against his scholarly writing. The book is a modernist urban novel set in a shantytown of Kingston, the Dungle, and is a shockingly graphic portrait of people living in grinding poverty. Its title gestures toward its engagement with Camus's absurdism, where the only hero is Sisyphus, "proletarian of the gods, powerless and rebellious." Patterson's second novel, An Absence of Ruins, deals with a historicity in a colonized land that has been denied the worthiness of great ruins. Its title is borrowed from Derek Walcott's poem The Royal Palms ... An Absence of Ruins. In a discussion of Absence of Ruins in London in 1967 Patterson explained that his understanding of sociology and art led him to publish the novel and his $\mathrm{PhD}$ dissertation on the sociology of Jamaican slavery in the same month. This was "the result not of intellectual schizophrenia but of a similar process "whereby one seeks to understand"' (quoted in Walmsley 1992, p. 77). An Absence of Ruins is experimental 
on a formal level in ways that point to a specific understanding of a "sociological" method as involving self-reflexivity.

All of this suggests that exploration of the concept of Social Death beyond the more familiar cases of slavery may still not be complete. In some of his recent work Patterson discusses contemporary forms of servitude such as human trafficking and penal labor. In globalization and anthropology, scholars have generally embraced his pioneering arguments about female slaves' capacity to imagine freedom, in spite of pernicious emotional and sexual exploitation (Chatterjee 2017).

Questions and debates about his work continue. One remaining question concerns the reasons sociology ignores certain questions and picks up on others. There is no obvious relation between the salience of topics within sociology and in parallel disciplines. Sociology has largely fallen back on a pre-1945 self-definition as the study of the modern, developed "self" as opposed to anthropology, construed as the study of the "other." Sociology also continuously slides back into a self-image as the study of the present. It is well established that social science disciplines repressed their own involvement in colonial research, after decolonization (Steinmetz 2017). Since sociologists largely ignored slavery (with a handful of exceptions, discussed in this volume), there was less to repress. Here the question is why slavery never managed to be recognized as a bona fide sociological topic.

Another pending question involves the question of colonialism with respect to the concept of Social Death. Patterson's work demonstrates that slavery often existed without empire or colonialism, and the converse is true as well. When western imperial powers turned their attention to Africa in the late nineteenth century, one of the widespread legitimating arguments was anti-slavery. For example, the abolition of Arab slaving was a key justification used by German colonizers for their assault on the Swahili Coast after 1884, leading to the colonization of German East Africa (Tanzania).

One of the similarities between modern colonialism and slavery involves the "rule of difference" in the former and manumission practices in the latter. Patterson suggests that slavery always includes the promise of manumission. However, he also argues that the freedman was often in a worse situation than the slave, due to systemic racism. (It seems less clear whether the freedman remained in a worse situation than citizens in Rome (see Greenland's article in this special issue or Bodel 2017), but in modern European slave colonies, this was definitely the case. Patterson repeatedly reminds his readers that freedmans' evidence was not accepted in seventeenth and eighteenth century courts, at least in British colonies; this was different from Latin America where freed slaves participated in the institutions of society.

Modern colonialism was premised on the claim that the conquered were inherently inferior and incapable of self-government. This was the case whether or not there was slavery or forced labor. There was, of course, widespread forced labor in African colonies before WWII (Cooper 2000). But even after 1945, through decolonization, Europeans remained under legal systems that were different from those of almost all of the colonized subjects. Modern European colonial legal systems were dualistic, with Europeans being subjected to European law and the colonized to some version of codified customary law. With the rule of colonial difference, the colonized were unfree, violently dominated, and generally dishonored. On the one hand, then, colonialism seems like a form of slavery. The main difference seems to be that there was not usually 
an effort to alienate the colonized "natally," especially since modern colonialism usually relied on some version of indirect rule (Lugard 1928), which did not try to separate the colonized from their ancestors and traditions but instead tried to rule them through these "natal" institutions. But with settler colonialism in the Americas, Australia, and New Zealand, the colonized were coercively separated from their indigenous traditions without being necessarily enslaved.

\section{Articles in this special issue}

\section{George Steinmetz}

Steinmetz argues that Patterson is an important contributor to postcolonial fiction and postcolonial theory, as well as historical sociology and social theory, and that his work contains crucial lessons for sociology in general. In addition to original concepts and historical interpretations, and social theory, this article argues that Patterson contributes specifically to postcolonial fiction and to a post-positivist understanding of historical sociology. Demonstrating this involves, first, reconstructing Patterson's early intellectual context, second, tracing the interplay between fiction and social analysis in his work, and third, combining Patterson's explicit epistemological arguments with the more implicit claims in his work.

Focusing on Patterson's three novels, Steinmetz argues that Patterson combines the métiers of sociologist and writer, yielding a formidable postcolonial oeuvre an alternative epistemology for social science, while contributing to a unique historical interpretation of slavery. To take one example, in An Absence of Ruins the main character is a Jamaican sociologist, Alexander Blackman, who studied in England. In addition to these parallels with Patterson's biography, Blackman is a vehicle for exploring some of the fateful logics examined in The Children of Sisyphus. Patterson is interested in the "loss of contact and solidarity" resulting from exile; Blackman exemplifies alienation at multiple levels. There is also a change in narrative voice from first- to third-person at the point when Blackman is revealed to be writing a book or keeping a diary. Steinmetz suggests that we can read this as a shift from spontaneous subjectivity to a more objectivizing vision, a form of self-reflexivity via self-objectification. Die the Long Day, Patterson's third novel, is a historical postcolonial novel and a work of postcolonial modernism. Patterson singles out the novel as preparing him for writing Slavery and Social Death by examining the subjectivity of the slaves. The novel's modernist form, Steinmetz argues, allows Patterson to foreground the humanity, agency, and conflicted experience of slaves.

The key components of Patterson's alternative approach to sociological analysis are: (1) exploring subjective or cultural conditions along with more objective social conditions, especially via fiction; (2) elimination of disciplinary anxieties about historians and historicism; (3) rejection of positivist doctrines of universal theory, value-free social science, a-culturalism, and methodological individualism and rationalism; and (4) approaching singularity and generalization via "universalizing from the particular." 


\section{John Bodel}

The starting point of John Bodel's article is that "the concepts of natal alienation and social death have become embedded in the theoretical apparatus of virtually all students of ancient Mediterranean societies" since the publication of Slavery and Social Death. This embeddedness has a history, and Bodel traces it through a momentous scholarly friendship between Orlando Patterson and Moses Finley, the Cambridge ancient historian who published extensively on slavery. Bodel draws on personal correspondence (some of it previously unpublished) to document the "changing of the guard in the way that ancient historians incorporate sociological methods and the social sciences generally into their thinking about slavery in the classical world." Beginning in 1978, when Patterson took up a visiting fellowship at Wolfson College, Cambridge, the two scholars exchanged letters and book manuscripts. Bodel concentrates on summer 1980, when Patterson asked Finley for comments on the penultimate version of his manuscript. It was a singular transdisciplinary moment. As Bodel argues, the interest of ancient historians in slavery shifted during the early 1980s from a focus on "external economic questions, characterized by an almost obsessive focus on the slave as laborer and the place of slavery in ancient 'modes of production', to investigation of internal sociological and psychological aspects of the institution centered on the workings of slave households in ancient society, manifestations of slave-owning ideology in classical culture, and the inner lives of Greek and Roman slaves." Although an interest in the major slave rebellions of Greco-Roman antiquity persisted, "the terms of the debate shifted around the same time, again partly under Finley's influence, from a predominantly Marxist focus on class struggles to a more Weberian interest in power relations and the role of charismatic leaders."

Finley and his ilk, including Geoffrey de St Croix and Keith Hopkins, were theoretical omnivores, incorporating ideas from Marxism, sociology, and cultural anthropology. Bodel credits the eclectic intellectual environment of late 1970s Oxbridge for some of Patterson's most powerful ideas, including the concept of social death, which drew on "classical Roman law and some theoretical reflections refined from it, ethnographic comparison, and what might be called personal experience, or at least familiarity, with life in the Caribbean." The original source material sheds important light on the mixed genealogy of Patterson's thought. The chapter traces the context of Patterson's evolving thinking in the period after the earlier periods discussed in Steinmetz's chapter. Bodel's discussion of the role of Finley and the classicists complements the reconstruction of the fields of West Indian artists and social science in the 1960s.

\section{Renisa Mawani}

The third article, by Renisa Mawani, demonstrates why close reading of Patterson's earlier writings is critical for appreciating in full his arguments in Slavery and Social Death. Mawani highlights two common criticisms of the social death concept: that it denies community to enslaved persons, and collapses together legal and social definitions of property and personhood. These criticisms, she argues, are wrong-headed. They overlook the apertures between master/slave, personhood/ property, and freedom/ unfreedom. Mawani, aligning herself with Patterson, insists that it is in these apertures 
that law operates, on many intermediate settings. The piece of the equation that is often overlooked, she avers, is the "peculiarly dual nature of the slave." As Patterson explained it, "On the one hand he was the property of another and was regarded as a disposable chattel. But it was impossible to deny that he was also a human being and the law had to be cognisant of this fact in some way" (Patterson 1967, p. 72). The nuances of this "doubleness" were worked out by Patterson in a series of publications about nineteenth century slave revolts in Jamaica. But the doubleness of the slave, she insists, was forged long before insurrection. Ocean crossings and ports of call, where African women, men, and children were commoditized, were the key sites for producing the person-property duality. Revolts tested this duality, as expressions of full personhood erupted in discontent. Mawani's remarkable examination of maritime law in the Anglo world suggests that the doubleness of person-property was not so peculiar after all. That doubleness was intentional, to accommodate legal plurality and economic heterogeneity across the Empire. And while the British Empire has faded from the map, its legal regime casts a long shadow over racialized inequalities today.

\section{Michael Ralph and Maya Singhal}

The legacy of Patterson's thesis of doubleness is traced through the contemporary scholarship on racial capitalism in the article by Michael Ralph and Maya Singhal. The term "racial capitalism," referring to the processes whereby racialism merged with capitalism, has seen an intensification of scholarly interest in recent years. It is now a stand-in for any practice of economic exploitation or targeting of black and brown people. The problem, Ralph and Singhal argue, is that few scholars bother to specify "race" or "capitalism," with the result that that the concept loses its explanatory power. Further, much of the work in this area has overlooked Patterson's work as formative for the essential ideas and methods that prefigure racial capitalism. To remedy this, the article sets Patterson's writings alongside Cedric Robinson's to show how the two thinkers together generate a nuanced critique of black exploitation, in slave markets and beyond. Published one year after Slavery and Social Death, Robinson's (1983) Black Marxism builds on Patterson's core insight concerning the autonomy of Africa and Afrodiasporic peoples. Like Patterson, Robinson situates the economic and political transformations that defined the Transatlantic slave trade in the social and economic transformations of the medieval period. But the two works also show important divergences, and Ralph and Singhal tease apart and reassemble the pieces in tension. Capitalism, they demonstrate, must now be expanded to take on processes of surveillance, accounting, and exploitation through the labor force as well as commercialization and provision (or denial) of public services. Drawing our attention once again to Patterson's work, the authors remind us that slavery is not the only system through which Black and brown people are bought and sold.

\section{Fiona Greenland}

The final article, by Fiona Greenland, challenges comparative and historical sociology's tendency toward presentism by tracing continuities in women's enslavement from antiquity to the transatlantic trade. In explicit conversation with Slavery and Social Death, she uses the concept of parasitism to ask what kinds of continuities can be 
captured at different moments in time and at different social positions. Change, rather than continuity, has been sociology's preoccupation, and this has conditioned the grounds for question-formation about slavery in the long-term (a theme taken up by Patterson 2004). The evidence from Roman Celtiberia, medieval Ragusa, and the African slave factories on the west coast of Africa indicates entrenched practices of parasitic use of captive female labor. The remarkable continuity of this practice has a number of implications. First, we can reject earlier arguments that slavery stopped being a "meaningful" or major socio-economic practice after late antiquity, and was started anew in the fifteenth century. Slavery was an ever-present feature of the Mediterranean basin, and female domestic servitude was embedded in culture, family, and the economy. Second, the specific evidence of enslaved women's funerary markers raises questions about the limits of "defying the forces of natal alienation and dishonor," to use Bodel's terms. It is simply not clear that enslaved women were given any expressive freedom in their funerary imagery, much less a proverbial parting jab at their owners. Social isolation and dishonor ensured that enslaved women had every incentive to comply and few opportunities to rebel. The entwining of parasitic institutional practices with ideas, images, and traditions (cultural motifs) of female domestic servitude permeated all aspects of society. Third, the etymology of "slave" is itself indicative of parasitic embeddedness: formally attached to Slavic men and women through the legal code of Ragusa, the Slav/slave became a recognizable, trusted brand of trained (female) slave. "Slave" was first an ethnonym, giving us a pre-Black Atlantic case of a group of people being condemnable to perpetual enslavement on the basis of racialized characteristics.

\section{Orlando Patterson}

Patterson has the final word. In his Afterword, he asks why sociologists have generally neglected the study of slavery despite the subject's obvious overlap with other core disciplinary concerns. "Sociology is the academic discipline that is most involved with the problem of race and inequality," he writes. "And yet, paradoxically, sociology is the discipline least concerned with the subject of slavery, a neglect that verges on disdain. Works on slavery rarely, if ever, appear in the pages of its leading journals. Graduate students steer clear of the subject."

The neglect of slavery as a specific focus, he argues, is the outcome of key shifts in the methods and concerns of comparative and historical sociologists. The first shift was toward "grand historical sociology," a tradition that emerged in the mid-to late seventies and early eighties, led by scholars including Theda Skocpol, Dietrich Rueschemeyer, and Peter B. Evans. This tradition used historical process-tracing and case comparison to chart the emergence of the modern world system. Within this tradition, slavery was treated as "one mode of labor production [among many], along with East European serfdom and Western wage labor" (Patterson, this issue).

Patterson clarifies that the problem extends beyond choice of methods and into the discipline's baseline scholarly orientation. Slavery, he explains, "became entangled with changing ideological fads and fashions in sociology. Up to the 1960s, slavery was, indeed, considered an essential factor in explaining racism and the plight of black Americans and blacks generally." But culture "became suspect among sociologists and the subject was largely dropped from sociological work on race and poverty" and 
excluded "as an explanatory factor in the study of race." The topic of slavery was "smeared through a kind of intellectual guilt by association" with the culture of poverty approach, "among sociologists." A view of slavery as "non-destructive of the social lives of the slaves" fitted neatly with the overall turn against cultural analysis in sociology in general and in the study of black life and poverty more specifically. "The fundamental issue at stake here is the misguided pseudo-liberal failure of sociologists, both those who work on present problems and historically oriented ones, to recognize one of the most tragic complexities of oppression. This is the fact that oppression works both externally and internally" (Patterson, this issue).

The second shift concerns presentism. Presentism is the dehistoricization of social phenomena, reflected in the temporal and regional parochialism of the papers published in the discipline's leading journals, the vast majority of which "usually do not indicate any era, period, or time frame, and are written in the sociological present tense" (Patterson, this issue, quoting Steinmetz 2018). This style of analysis "conveys an image of the social world as being governed by unchanging universal laws and logics of necessity. The message is that the present is the same as the past, or that the past is simply not interesting ..." (ibid.)

Slavery was one of the foundational institutions of western civilization. It was one of the foundational institutions of the United States. As the articles in this special issue of Theory and Society demonstrate, a fully historicized treatment of the subject, attendant to its specific manifestations and consequences, is Patterson's bequest to us.

\section{References}

Arendt, H. (1951). The origins of totalitarianism. New York: Harcourt, Brace.

Bodel, J., \& Scheidel, W. (Eds.). (2017). On human bondage: After slavery and social death. Chichester, West Sussex: Wiley Blackwell.

Bodel, J. (2017). Death and social death in ancient Rome. In J. Bodel \& W. Scheidel (Eds.), On human bondage: After slavery and social death (pp. 81-108). Chichester, West Sussex: Wiley Blackwell.

Bourdieu, P. (2013). Séminaires sur le concept de champ, 1972-1975. Actes de la Recherche en Sciences Sociales, 200, 4-37.

Buggeln, M. (2008). Were concentration camp prisoners slaves? The possibilities and limits of comparative history and global historical perspectives. International Review of Social History, 53, 101-129.

Buggeln, M. (2014). Slave Labor in Nazi Concentration Camps. Oxford: Oxford University Press.

Chatterjee, I. (2017). The locked box in Slavery and Social Death. In J. Bodel \& W. Scheidel (Eds.), On Human Bondage: After slavery and social death (pp. 151-167). Chichester, West Sussex: Wiley Blackwell.

Cooper, F. (2000). Conditions analogous to slavery. Imperialism and free labor ideology in Africa. In F. Cooper, T. C. Holt, \& R. J. Scott (Eds.), Beyond Slavery: Explorations of Race, Labor, and Citizenship in Postemancipation Societies (pp. 107-156). Chapel Hill: University of North Carolina Press.

Güttler, N., Pratschke, M., \& Stadler, M. (2016). Wissen, ca. 1980. Zürcher Jahrbuch für Wissensgeschichte, $12,1-14$.

Kaplan, M. A. (1998). Between dignity and despair: Jewish life in Nazi Germany. New York: Oxford University Press.

Kühne, T. (2013). Colonialism and the holocaust: Continuities, causations, and complexities. Journal of Genocide Research, 15(3), 339-362.

Laclau, E., \& Mouffe, C. (1985). Hegemony and socialist strategy: Towards a radical democratic politics. London: Verso.

Luft, A. (2017). Has the 2016 election institutionalized systemic social exclusion and violence in AmericaAnd perhaps paved the way for authoritarianism and the possible Social Death of groups perceived as undesirable to the new Administration in Washington? Jewish Social Studies, 22(3), 203-211. 
Lugard, F. (1928). Representative forms of government and "indirect rule" in British Africa. Edinburgh: W. Blackwood \& Sons.

Mamdani, M. (1996). Citizen and subject: Contemporary Africa and the legacy of late colonialism. Princeton: Princeton University Press.

Mitchell, T. (1988). Colonising Egypt. Cambridge \& New York: Cambridge University Press.

Patterson, O. (1964 [2012]). The children of Sisyphus. Leeds: Peepal Tree.

Patterson, O. (1967). The sociology of slavery: Jamaica, 1655-1838. London: MacGibbon \& Kee.

Patterson, O. (1982). Slavery and social death: A comparative study. Cambridge: Harvard University Press.

Patterson, O. (1991). Freedom in the making of Western culture. New York: Basic Books.

Patterson, O. (2004). Culture and continuity: Causal structures in socio-cultural persistence. In R. Friedland \& J. Mohr (Eds.), Matters of culture: Cultural sociology in practice (pp. 71-109). New York: Cambridge University Press.

Said, E. W. (1979). Orientalism. New York: Vintage Books.

Scott, D. (2013). The paradox of freedom: An interview with Orlando Patterson. Small Axe: A Caribbean Journal of Criticism, 17(40), 96-242.

Steinmetz, G. (2005). American Sociology's epistemological unconscious and the transition to post-Fordism: The case of historical sociology. In J. Adams, E. Clemens, \& A. Orloff (Eds.), Remaking modernity: Politics, processes and history in sociology (pp. 109-157). Durham: Duke University Press.

Steinmetz, G. (2007). The Devil's handwriting: Precoloniality and the German colonial state in Qingdao, Samoa, and Southwest Africa. Chicago: University of Chicago Press.

Steinmetz, G. (2017). Sociology and colonialism in the British and French empires, 1940s-1960s. Journal of Modern History, 89(3), 601-648.

Steinmetz, G. (2018). Arguments for a comparative and historical sociology section of the ASA. Trajectories: Newsletter of the ASA Comparative and Historical Sociology Section 29(3), spring 2018.

Steinmetz, G. (forthcoming). Concept-Quake: Toward a Historical Sociology of Social Science. In D. Fassin \& G. Steinmetz (Eds.), The Social Sciences Through the Looking-Glass. Studies in the Production of Knowledge. Oxford: Oxford University Press.

Steinmetz, G. (Ed.). (1999). State/Culture. State Formation after the Cultural Turn, edited by G. Steinmetz. Ithaca, NY: Cornell University Press.

Walmsley, A. (1992). The Caribbean artists movement, 1966-1972: A literary and cultural history. London: New Beacon Books.

Weber, A. (1997). Schriften zur Kultur- und Geschichtssoziologie (1906-1958). Alfred-WeberGesamtausgabe, vol. 8. Marburg: Metropolis.

Oakes, G. (1988). Weber and Rickert: Concept formation in the cultural sciences. Cambridge: MIT Press.

Whitman, J. Q. (2017). Hitler's American model: The United States and the making of Nazi race law. Princeton: Princeton University Press.

Williams, R. (1995). Orlando Patterson interview. Sociological Forum, 10(4), 653-671.

Zimmerer, J. (2004). Colonialism and the holocaust. Towards an archeology of genocide. In A. D. Moses (Ed.), Genocide and settler society: Frontier violence and stolen indigenous children in Australian history (pp. 49-76). New York: Berghahn.

Publisher's note Springer Nature remains neutral with regard to jurisdictional claims in published maps and institutional affiliations. 